\title{
Cancer stem cells as a potential therapeutic target in thyroid carcinoma (Review)
}

\author{
LUISA VICARI $^{1}$, CRISTINA COLAROSSI ${ }^{2}$, DARIO GIUFFRIDA ${ }^{2}$, \\ RUGGERO DE MARIA ${ }^{3}$ and LORENZO MEMEO ${ }^{1,2}$ \\ ${ }^{1}$ Cell Biology Unit, IOM Ricerca Srl; ${ }^{2}$ Department of Experimental Oncology, Mediterranean Institute of Oncology, \\ Viagrande, I-95029 Catania; ${ }^{3}$ Regina Elena National Cancer Institute, I-00144 Rome, Italy
}

Received March 4, 2016; Accepted May 24, 2016

DOI: $10.3892 / 01.2016 .4936$

\begin{abstract}
A number of studies have indicated that tumor growth and proliferation is dependent on a small subset of cells, defined as cancer stem cells (CSCs). CSCs have the capability to self-renew, and are involved with cancer propagation, relapse and metastatic dissemination. CSCs have been isolated from numerous tissues, including normal and cancerous thyroid tissue. A regulatory network of signaling pathways and microRNAs (miRNAs) control the properties of CSCs. Differentiated thyroid carcinoma is the most common type of endocrine cancer, with an increasing incidence. Anaplastic thyroid carcinoma is the most rare type of endocrine cancer; however, it also exhibits the highest mortality rate among thyroid malignancies, with an extremely short survival time. Thyroid CSCs are invasive and highly resistant to conventional therapies, including radiotherapy and chemotherapy, which results in disease relapse even when the primary lesion has been eradicated. Therefore, targeting thyroid CSCs may represent an effective treatment strategy against aggressive neoplasms, including recurrent and radioresistant tumors. The present review summarizes the current literature regarding thyroid CSCs and discusses therapeutic strategies that target these cells, with a focus on the function of self-renewal pathways and miRNAs. Elucidation of the mechanisms that regulate CSC growth and survival may improve novel therapeutic approaches for treatment-resistant thyroid cancers.
\end{abstract}

\section{Contents}

1. Introduction

2. CSCs

Correspondence to: $\mathrm{Dr}$ Lorenzo Memeo, Department of Experimental Oncology, Mediterranean Institute of Oncology, Via Penninazzo 7, Viagrande, I-95029 Catania, Italy

E-mail: lorenzo.memeo@grupposamed.com

Key words: thyroid cancer stem cells, effective strategies
3. Thyroid CSCs

4. Therapeutic strategies

5. Conclusion

\section{Introduction}

Thyroid cancer is the most common type of endocrine malignancy (1). According to the World Health Organization, thyroid cancer may be classified into four subtypes based on its histopathological characteristics: Papillary thyroid carcinoma (PTC), follicular thyroid carcinoma (FTC), medullary thyroid carcinoma (MTC) and anaplastic thyroid carcinoma (ATC) (2). PTC accounts for $80-85 \%$ of all thyroid cancers, while FTC accounts for 10-15\% of cases. PTC and FTC are well-differentiated cancers and, if detected early, exhibit a favorable prognosis. MTC arises from the parafollicular $\mathrm{C}$ cells of the thyroid and accounts for $\sim 5 \%$ of all thyroid cancers. ATC, which is defined as undifferentiated thyroid cancer (UTC), is a rare, aggressive and lethal malignancy that exhibits rapid disease progression (3). Although ATC accounts for only $1 \%$ of all thyroid cancers, it accounts for $>50 \%$ of mortalities that are associated with thyroid carcinoma, with a median survival time of 6-8 months $(4,5)$.

Thyroid cancer treatments include surgery, radioiodine therapy and chemotherapy $(6,7)$. Notably, survival rates have not significantly increased in recent years, which indicates that certain thyroid tumors are resistant to the current therapeutic modalities (8).

The identification of cancer stem cells (CSCs) in a number of tumor types represents a crucial step for the development of effective therapies $(9,10)$. CSCs are a population of cells that have the capacity to self-renew and initiate tumors. Furthermore, when transplanted into immunodeficient nonobese diabetic/severe combined immunodeficiency (NOD/SCID) mice, CSCs lead to regeneration of the original cancer (11).

CSCs have been identified in a number of solid tumors and hematological malignancies (12-24). Similarly, CSCs have been identified in thyroid cancer; however, their function in this tumor type remains to be fully determined (25).

The resistance of CSCs to conventional treatments may provide a biological basis for understanding tumor recurrence (26). Eradication of CSCs is considered a primary goal 
of cancer therapy (27). Therefore, increased understanding of the characteristics of thyroid CSCs and the identification of therapeutic agents that target the CSC population may lead to the development of novel treatments that specifically target ATC and advanced forms of differentiated tumors.

The present review summarizes the characteristics of thyroid CSCs and discusses potential approaches for targeting thyroid CSCs that may be used in combination with the current therapeutic modalities to achieve long-lasting effects and avoid tumor recurrence and progression.

\section{CSCs}

Two major models account for the heterogeneity of tumors: The stochastic/clonal evolution and the CSC models (28).

The first model postulates that each cell within a tumor exhibits a tumorigenic potential that is uniquely driven by the acquisition of novel genetic mutations and epigenetic changes that favor clonal selection (29). The second model hypothesizes that only a subpopulation of tumor stem cells possess high tumorigenic activity, representing a hierarchical organization similar to that observed in normal tissue (30). The clinical implication of the CSC model is that the elimination of all CSCs arrests tumor growth, whereas the failure to eliminate CSCs will eventually lead to tumor relapse (28).

CSCs are a small subpopulation of cancer cells characterized by self-renewal, with the capacity to differentiate into several tumor cell types and metastasize (31).

In contrast to differentiated tumor cells, CSCs are relatively quiescent, exhibit a slow cycling rate and exist in a 'stem cell niche' that regulates self-renewal and differentiation (32).

CSCs survive in serum-free conditions and proliferate as cellular solid clusters termed 'tumor spheres' (10). Furthermore, CSCs form tumors when injected into immunodeficient mice $(33,34)$.

Bonnet and Dick (12) first reported the existence of a CSC population in 1997. The authors identified a population of leukemic stem cells in human acute myeloid leukemia and demonstrated that CSCs initiated leukemia in NOD/SCID mice (12).

In 2003, Al-Haj et al (13) were the first to identify CSCs in a tumor of the breast. Subsequently, CSCs have been identified in a number of other solid tumors, including tumors in the brain (14), prostate (15), colon (16-18), head and neck (19), lung (20), melanoma (21), liver (22), ovary (23) and pancreas (24).

CSCs may be isolated by flow cytometry according to the expression of several markers, detection of side-population (SP) phenotypes by Hoechst 33342 exclusion and expression of cytoprotective enzymes such aldehyde dehydrogenase (ALDH)

A number of CSCs markers have been identified, including cluster of differentiation (CD)34+/CD38- in leukemia (12), CD44+/epithelial surface antigen (ESA)+/CD24- in breast cancer (13), CD133+ in brain (14), colorectal (18), lung (20) and endometrial cancer (35), CD44+/CD24+/ESA+ in pancreatic cancer (36), CD44+/CD117+ in ovarian cancer (37), CD44+/CD271+ in head and neck squamous cell carcinoma (38), CD90 in liver cancer (39), CD105 in kidney cancer (40), and CD271 in melanoma (41), hypopharyngeal carcinoma (42) and osteosarcoma (43).
In addition, recent evidence indicates that ephrin (Eph) tyrosine kinase receptors and their ligands, Ephs, sustain CSC self-renewal capacity, viability, invasiveness and tumorigenicity $(44,45)$.

Recently, EphA2 has been reported to exhibit a significant function in the regulation of glioblastoma (46) and lung CSCs (47). However, the association between EphA2 and thyroid CSCs remains unclear.

A small subset of cells, termed SP cells, have been isolated from various solid tumors, including normal and neoplastic thyroid cells, using flow cytometric analysis (48). SP cells exclude the DNA binding dye Hoechst 33342, and are highly enriched for stem cells (49). The efflux of Hoechst dye is dependent on the expression of the adenosine triphosphate-binding cassette (ABC) family of membrane transporters; when overexpressed in cancer cells, they export anticancer drugs, leading to drug resistance (50).

ALDH is a nicotinamide adenine dinucleotide phosphate+-dependent enzyme that is involved in the detoxification of intracellular aldehydes to weak carboxylic acids (51). Recently, a high level of ALDH activity has been identified as a characteristic of CSCs, and the ALDEFLUOR ${ }^{\mathrm{TM}}$ flow cytometric assay has been widely used for the isolation and study of CSCs in various cancer types $(52,53)$.

\section{Thyroid CSCs}

CSCs exhibit an important function in malignant progression, therapeutic resistance and recurrence of thyroid cancer (54-56).

Two models of thyroid carcinogenesis exist: Multi-step carcinogenesis and fetal cell carcinogenesis (57-59). The first model hypothesizes that thyroid cancer cells are derived from thyrocytes via genomic changes (57-59). The second model postulates that thyroid tumor cells originate from the remnants of three types of fetal thyroid cells that persist until early childhood: Thyroid stem cells, thyroblasts and prothyrocytes (57-59).

Cancer cells may also originate from more differentiated cells that have acquired stem-like characteristics via genetic alterations and epithelial-mesenchymal transition (EMT) (60). EMT is a mechanism that generates further CSCs with increased invasiveness and a metastatic phenotype (61). In addition, EMT exerts a critical function in tumor recurrence, and is associated with a loss of E-cadherin expression by genes that repress E-cadherin, including Snail, Slug, zinc-finger E-box-binding (ZEB)1, ZEB2 and Twist1 (62). During EMT, cells become less adherent, lose polarity and acquire an invasive phenotype (63).

Thyroid CSCs are identified due to their expression of biomarkers and their ability to form thyrospheres in vitro and tumors in vivo (64).

Zito et al (65) first attempted to isolate CSCs in 2008, and analyzed the expression of CD133 by flow cytometry in thyroid cancer cell lines. Subsequently, Friedman et al (66) demonstrated that the transplantation of CD133+ cells into immunodeficient NOD/SCID mice was sufficient to induce tumor growth in vivo. However, these results were considered controversial, as Schweppe et al (67) evaluated 40 thyroid cancer cell lines using short tandem repeat and single nucleotide polymorphism array analyses, and reported that a number of the cell lines tested were 
redundant or did not originate from the thyroid. These results indicated that CSCs should be isolated from human thyroid biopsy specimens rather than cell lines.

Using ALDH as a marker, Todaro et al (68) were the first group to isolate thyroid CSCs from primary thyroid carcinomas. These cells are most common in UTC $(5 \%)$, followed by PTC (2\%) and FTC (1-2\%). Todaro et al (68) expanded such thyroid CSCs populations as thyrospheres, which retain tumorigenic potential and ALDH1 and CD44 expression, but are negative for CD133 expression.

The authors demonstrated that cells exhibiting high ALDH expression $\left(\mathrm{ALDH}^{\mathrm{high}}\right)$ were capable of self-renewal and thus, unlimited replication (68). As UTC CSCs are highly malignant, these cells undergo a higher number of symmetric divisions than PTC and FTC CSCs (68). Therefore, thyrospheres may present a potential tool for preclinical studies. Todaro et al (68) also demonstrated that orthotopic injection of 100 thyroid CSCs into the mouse thyroid gland recapitulated the behavior of the parental tumor, including local spreading and formation of distant metastases. As expected, the migration capability of $\mathrm{ALDH}^{\text {high }}$ cells derived from UTC was higher than that of FTC or PTC (68). Furthermore, ALDH ${ }^{\text {high }}$ UTC cells aggressively invaded the trachea and esophagus, and metastasized to distant locations, including the lung (68). By contrast, FTC and PTC CSCs developed moderately invasive tumors (68). The authors further demonstrated that the cell migration capacity was associated with increased c-Met (hepatocyte growth factor receptor) and Akt (a serine/threonine protein kinase) expression (68). These results indicated that c-Met and/or Akt may represent potential therapeutic targets in thyroid cancer.

Malaguarnera et al $(69,70)$ also identified CSCs in PTC, and demonstrated that CSCs, isolated as thyrospheres, expressed octamer-binding transcription factor 4, sex determining region Y-box 2 (SOX2), Nanog, CD133 and CD44 stem cell markers. Additionally, the expression of the insulin receptor (IR) isoforms (IR-A and IR-B), insulin-like growth factor (IGF)-IR, IGF-I and IGF-II was higher in CSCs than in differentiating cells.

Li et al (71) isolated tumor stem cells from anaplastic thyroid cancer cell lines (THJ-11T, THJ-16T, THJ-21T and THJ-29T), and demonstrated that a subpopulation of these cells expressed the stem cell markers POU class 5 homeobox 1 (POU5F1) and Nanog, and formed tumors in immunodeficient mice. Notably, none of the cell lines expressed CD133.

Ahn et al (72) isolated thyroid CSCs from the TPC-1 PTC cell line and 11 human specimens. These CD44+CD24- cells expressed the stem cell marker POU5F1, and a higher percentage of these cells were identified in clinically aggressive recurrent PTCs compared with less aggressive primary PTCs. Furthermore, only $20 \%$ of mice inoculated with these CD44+CD24- CSCs generated tumors, as PTC is significantly less tumorigenic than undifferentiated ATC.

Furthermore, to identify specific thyroid CSC markers, Shimamura et al (73) investigated the expression of nine cell surface markers (CD13, CD15, CD24, CD44, CD90, CD117, CD133, CD166 and CD326), as well as ALDH activity and the ability to form spheres in vitro and tumors in vivo, in eight thyroid cancer cell lines (FRO, KTC1/2/3, TPC1, WRO, ACT1 and $8505 \mathrm{C})$. The results indicated that ALDH activity represents a candidate marker.

\section{Therapeutic strategies}

At present, the molecular pathogenesis of thyroid carcinoma remains unclear and in particular, little is known regarding the development of ATC. Conventional therapies target mature cancer cells and thus, thyroid CSCs, which are relatively quiescent and intrinsically resistant, are not eradicated (74,75). CSCs efficiently repair DNA damage following exposure to cytotoxic injury, and are therefore capable of reconstituting the original tumor (74). In consequence, it is important to identify novel therapeutic approaches that target thyroid CSCs (76-78).

Possible strategies to destroy thyroid CSCs and overcome chemo- and radioresistance may involve the following: Increasing sensitization of CSCs directly using agents that kill CSCs specifically or promote their differentiation; targeting and blocking important CSCs signaling pathway components, including signal transducer and activator of transcription 3 (STAT3), c-Met, SOX2, rearranged during transfection (RET), CD44, ABC sub-family $\mathrm{G}$ member (ABCG)2 and ABCB1; and destroying CSC niches (79).

STAT3 is a transcription factor that regulates cell cycle progression, matrix cellular invasion and angiogenesis (80). A previous study revealed that STAT3 is constitutively activated in numerous cancer types, indicating that it exhibits an important function in resistance to chemoradiotherapy (81).

Tseng et al (82) demonstrated that the STAT3 signaling pathway is required for the self-renewal of CD133+ ATC cells. The authors revealed that combined treatment with cucurbitacin and radiochemotherapy blocked STAT3 activity, which suppressed CD133+ cell survival and tumorigenesis in vitro and in vivo (82).

c-Met, an oncogene that encodes the c-Met protein, controls the motility and mitogenesis of epithelial cells, including cancer cells (83). In thyroid cancer, c-Met activation induces proliferation, invasion and angiogenesis, contributing to tumor growth and cell spreading (84). Todaro et al (68) revealed that silencing of c-Met completely abrogates the metastatic capacity of thyroid CSCs. These results indicate that c-Met is a potential therapeutic target in thyroid cancer treatment.

Metastatic MTC responds poorly to conventional treatments with chemotherapy and radiotherapy (85). The RET signaling pathway is involved in stem cell maintenance and the development of MTC (86). Inhibition of RET expression reduces MTC sphere formation, indicating that this may represent a possible therapeutic objective (87).

ABCG2 and ABCB1, members of the ABC transporter family, are involved in multiple drug resistance (88). Zheng et al (89) revealed that the failure of doxorubicin treatment in ATC may be explained by the upregulation of ABCG2 and ABCB1 in thyroid CSCs. The development of therapeutic strategies that directly target $\mathrm{ABC}$ transporters may present a useful method for killing thyroid CSCs.

CSCs exist in a specific stem cell niche, which has a special microenvironment that controls their self-renewal and maintains their undifferentiated state (32). The CSC niche is composed of various stromal cells types, and includes a vascular system, mesenchymal and immune cells, an extracellular matrix, and soluble factors (90). These stromal cells maintain the CSCs in a quiescent state, and regulate their self-renewal and differentiation via the modulation of several 
signaling pathways (90). In addition, the CSC niche appears to be important for metastasis formation via induction of EMT (32). Furthermore, it enhances therapy resistance by protecting CSCs from various genotoxic insults (32).

Knowledge regarding the microenvironment of the CSC niche remains limited and requires further investigation. The vasculature is a promising target in the microenvironment of the CSC niche, as inhibition of angiogenesis and depletion of blood vessels may destroy CSC niches and inhibit tumor growth (91). Understanding the association between CSC niches and their microenvironments may lead to the development of innovative thyroid cancer treatments (92).

Finally, microRNAs (miRNAs or miRs), which are small non-coding RNAs ( 21 nucleotides), are aberrantly expressed or lost in a variety of cancers (93). Generally, miRNAs bind to the 3'-untranslated regions of target messenger RNAs (mRNAs), resulting in mRNA degradation or inhibition of translation (94).

miRNAs that are upregulated in cancer may function as oncogenes and promote cancer development by negatively regulating tumor suppressor genes (95). By contrast, miRNAs that are frequently downregulated may function as tumor suppressors to inhibit cancer development via downregulation of oncogenes (96).

Recent studies have indicated that miRNAs may represent potential targets for novel therapies in aggressive thyroid carcinomas (97). The function of miRNAs in various thyroid tumors is unclear; however, certain miRNAs may represent useful diagnostic tools $(98,99)$.

It has been demonstrated that numerous miRNAs are transcriptionally upregulated or deregulated in PTC compared with healthy thyroid tissue (100-109), in FTC compared with follicular adenoma (110-112); in MTC $(113,114)$ and in ATC (115-117).

Furthermore, the use of miRNAs as circulating biomarkers in thyroid cancer is gaining increasing attention (118). Lee et al (119) demonstrated that plasma levels of miR-222 and miR-146b are associated with PTC recurrence.

Several miRNAs regulate CSCs properties, including self-renewal ability, tumorigenicity and drug resistance (120-123). CSCs have generally high levels of oncogenic miRNAs and low levels of tumor suppressive miRNAs (122).

To the best of our knowledge, no miRNAs have been identified in thyroid CSCs. Notably, a recent study demonstrated that miRNAs control CSC functions and regulate cancer progression by affecting EMT (124). Therefore, a more detailed understanding of how miRNAs control the EMT process and regulate CSC function may lead to the clinical application of miRNAs in thyroid cancer diagnosis, treatment and prognosis.

Finally, investigation of thyroid stem cell regulation by Eph receptors and Ephs may lead to the identification of novel targets for therapeutic intervention in thyroid cancer.

\section{Conclusion}

Thyroid cancer remains a major public health issue (8). Of all thyroid cancers, $>90 \%$ of cases are well-differentiated and generally exhibit a favorable prognosis (3). By contrast, ATC, an UTC, is associated with a poor prognosis (3).
At present, surgery, radiation therapy, chemotherapy and hormonal therapy are used to treat thyroid cancer; however, these treatments often exhibit limited efficacy (7).

Conventional therapies target highly proliferating cells that form the majority of the tumor mass, but they are ineffective against slowly proliferating or quiescent CSCs, which are responsible for drug resistance, metastasis and recurrence (125).

Therefore, an ideal therapy would eliminate both CSCs and their progeny. Although certain advances have been made, the absence of important information regarding the underlying mechanisms of increased expansion and survival of thyroid cancer cells has prevented the development of reliable treatments.

The ability to identify, isolate and study thyroid CSCs has a number of implications with potential novel therapeutic consequences: i) Their molecular characterization and elucidation of the relevant signaling pathways will allow the identification of novel diagnostic markers and therapeutic targets; ii) an extensive analysis of gene expression levels may reveal the existence of unknown regulatory pathways that control CSCs; iii) CSCs may be useful for preclinical therapeutic screening and for monitoring the effects of novel biological therapies; and iv) knowledge of CSC behavior within the four subtypes of thyroid cancer may lead to the development of subtype specific treatments.

Future studies that investigate the molecular pathways responsible for thyroid CSC survival and expansion are required to increase the understanding of thyroid CSCs and to identify relevant therapeutic targets. Drugs that specifically target thyroid CSCs with minimal side effects are required. In addition, elucidating the associations between thyroid CSCs, differentiated tumor cells and the microenvironment is essential.

Finally, considering the importance of thyroid CSCs, this field of study has become an essential step for the development of targeted, selective and individualized treatment to achieve complete eradication of thyroid cancer.

\section{Acknowledgements}

The authors would like to thank Dr Rosario Gulino for his helpful assistance and Dr Raffaella Giuffrida for the critical reading of the present manuscript, both of the Cell Biology Unit, IOM Ricerca Srl (Viagrande, Italy).

The present study was partially funded by the Italian National Operational Program Research and Competitiveness (Rome, Italy; grant no. PON 01_1078 'Identification of biomarkers and development of diagnostic and therapeutic methods in the field of oncology and vascular biology').

\section{References}

1. Viola D, Valerio L, Molinaro E, Agate L, Bottici V, Biagini A, Lorusso L, Cappagli V, Pieruzzi L, Giani C, et al: Treatment of advanced thyroid cancer with targeted therapies: Ten years of experience. Endocr Relat Cancer 23: R185-R205, 2016.

2. World Health Organization: WHO Classification of Tumours, Volume 8. Pathology and Genetics of Tumours of Endocrine Organs. Third edition. IARC Press, Lyon, pp73-76, 2004.

3. Sherman SI: Thyroid carcinoma. Lancet 361: 501-511, 2003.

4. Nagaiah G, Hossain A, Mooney C, Parmentier J and Remick SC: Anaplastic thyroid cancer: A review of epidemiology, pathogenesis, and treatment. J Oncol 2011: 542358, 2011. 
5. Perri F, Lorenzo GD, Scarpati GD and Buonerba C: Anaplastic thyroid carcinoma: A comprehensive review of current and future therapeutic options. World J Clin Oncol 2: 150-157, 2011.

6. Giuffrida D, Prestifilippo A, Scarfia A, Martino D and Marchisotta S: New treatment in advanced thyroid cancer. J Oncol 2012: 391629, 2012.

7. Jin S, Borkhuu O, Bao W and Yang YT: Signaling Pathways in thyroid cancer and their therapeutic implications. J Clin Med Res: 284-296, 2016.

8. Regalbuto C, Frasca F, Pellegriti G, Malandrino P, Marturano I, Di Carlo I and Pezzino V: Update on thyroid cancer treatment. Future Oncol 8: 1331-1348, 2012.

9. Podberezin M, Wen J and Chang CC: Cancer stem cells: A review of potential clinical applications. Arch Pathol Lab Med 137: 1111-1116, 2013

10. Singh SR: Cancer stem cells: Recent developments and future prospects. Cancer Lett 338: 1-2, 2013.

11. O'Brien CA, Kreso A and Jamieson CH: Cancer stem cells and self-renewal. Clin Cancer Res 16: 3113-3120, 2010.

12. Bonnet D and Dick JE: Human acute myeloid leukemia is organized as a hierarchy that originates from a primitive hematopoietic cell. Nat Med 3: 730-737, 1997.

13. Al-Haj JM, Wicha MS, Benito-Hernandez A, Morrison SJ and Clarke MF: Prospective identification of tumorigenic breast cancer cells. Proc Natl Acad Sci USA 100: 3983-3988, 2003

14. Singh SK, Hawkins C, Clarke ID, Squire JA, Bayani J, Hide T, Henkelman RM, Cusimano MD and Dirks PB: Identification of human brain tumour initiating cells. Nature 432: 396-401, 2004

15. Collins AT, Berry PA, Hyde C, Stower MJ and Maitland N: Prospective identification of tumorigenic prostate cancer stem cells. Cancer Res 65: 10946-10951, 2005.

16. Ricci-Vitiani L, Fabrizi E, Palio E and De Maria R: Colon cancer stem cells. J Mol Med (Berl) 87: 1097-1104, 2009.

17. Ricci-Vitiani L, Pagliuca A, Palio E, Zeuner A and De Maria R Colon cancer stem cells. Gut 57: 538-548, 2008.

18. Ricci-Vitiani L, Lombardi DG, Pilozzi E, Biffoni M, Todaro M, Peschle C and De Maria R: Identification and expansion of human colon-cancer-initiating cells. Nature 445: 111-115, 2007.

19. Prince ME, Sivanandan R, Kaczorowski A, Wolf GT, Kaplan MJ, Dalerba P, Weissman IL, Clarke MF and Ailles LE: Identification of a subpopulation of cells with cancer stem cell properties in head and neck squamous cell carcinoma. Proc Natl Acad Sci USA 104: 973-978, 2007.

20. Eramo A, Lotti F, Sette G, Pilozzi E, Biffoni M, Di Virgilio A Conticello C, Ruco L, Peschle C and De Maria R: Identification and expansion of the tumorigenic lung cancer stem cell population. Cell Death Differ 15: 504-514, 2008

21. Schatton T and Frank MH: Cancer stem cells and human malignant melanoma. Pigment Cell Melanoma Res 21: 39-55, 2008.

22. Yang ZF, Ho DW, Ng MN, Lau CK, Yu WC, Ngai P, Chu PW, Lam CT, Poon RT and Fan ST: Significance of CD90+ cancer stem cells in human liver cancer. Cancer Cell 13: 153-166, 2008

23. Curley MD, Therrien VA, Cummings CL, Sergent PA, Koulouris CR, Friel AM, Roberts DJ, Seiden MV, Scadden DT, Rueda BR and Foster R: CD133 expression defines a tumor initiating cell population in primary human ovarian cancer. Stem Cells 27: 2875-2883, 2009.

24. Li C, Heidt DG, Dalerba P, Burant CF, Zhang L, Adsay V, Wicha M, Clarke MF and Simeone DM: Identification of pancreatic cancer stem cells. Cancer Res 67: 1030-1037, 2007.

25. Lin RY: Thyroid cancer stem cells. Nat Rev Endocrinol 7 : 609-616, 2011

26. Maugeri-Saccà $\mathrm{M}$, Vigneri $\mathrm{P}$ and De Maria R: Cancer stem cells and chemosensitivity. Clin Cancer Res 17: 4942-4927, 2011

27. Giuffrida R, Adamo L, Iannolo G, Vicari L, Giuffrida D, Eramo A, Gulisano M, Memeo L and Conticello C: Resistance of papillary thyroid cancer stem cells to chemotherapy. Oncology Letters 12: 687-691, 2016.

28. Nguyen LV, Vanner R, Dirks P and Eaves CJ: Cancer stem cells: An evolving concept. Nat Rev Cancer 12: 133-143, 2012.

29. Shackleton M: Normal stem cells and cancer stem cells: Similar and different. Semin Cancer Biol 20: 85-92, 2010

30. Sengupta A and Cancelas JA: Cancer stem cells: A stride towards cancer cure? J Cell Physiol 225: 7-14, 2010.

31. Shiozawa Y, Nie B, Pienta KJ, Morgan TM and Taichman RS: Cancer stem cells and their role in metastasis. Pharmacol Ther 138: 285-293, 2013.

32. Borovski T, De Sousa E Melo F, Vermeulen L and Medema JP: Cancer stem cell niche: The place to be. Cancer Res 71: 634-639, 2011.
33. Yu Z, Pestell TG, Lisanti MP and Pestell RG: Cancer stem cells Int J Biochem Cell Biol 44: 2144-2151, 2012.

34. Clevers H: The cancer stem cell: Premises, promises and challenges. Nat Med 17: 313-319, 2011

35. Rutella S, Bonanno G, Procoli A, Mariotti A, Corallo M Prisco MG, Eramo A, Napoletano C, Gallo D, Perillo A, et al: Cells with characteristics of cancer stem/progenitor cells express the CD133 antigen in human endometrial tumors. Clin Cancer Res 15: 4299-4311, 2009.

36. Padhye SS, Guin S, Yao HP, Zhou YQ, Zhang R and Wang MH Sustained expression of the RON receptor tyrosine kinase by pancreatic cancer stem cells as a potential targeting moiety for antibody-directed chemotherapeutics. Mol Pharm 8: 2310-2319, 2011

37. Zhang SC, Balch MW, Chan HC, Lai D, Matei JM, Schilder PS, Yan PS, Huang TH and Nephew KP: Identification and characterization of ovarian cancer-initiating cells from primary human tumors. Cancer Res 68: 4311-4320, 2008.

38. Murillo-Sauca O, Chung MK, Shin JH, Karamboulas C, Wok SK, Jung YH, Oakley R, Tysome JR, Farnebo LO, Kaplan MJ, et al: CD271 is a functional and targetable marker of tumor-initiating cells in head and neck squamous cell carcinoma. Oncotarget 5: 6854-6866, 2014

39. Tomuleasa C, Soritau O, Rus-Ciuca D, Pop T, Todea D, Mosteanu O, Pintea B, Foris V, Susman S, Kacsó G and Irimie A: Isolation and characterization of hepatic cancer cells with stem-like properties from hepatocellular carcinoma. J Gastrointestin Liver Dis 19: 61-67, 2010.

40. Bussolati B, Bruno S, Grange C, Ferrando U and Camussi G: Identification of a tumor-initiating stem cell population in human renal carcinomas. FASEB J 22: 3696-3705, 2008

41. Boiko AD, Razorenova OV, Van de Rijn M, Swetter SM, Johnson DL, Ly DP, Butler PD, Yang GP, Joshua B, Kaplan MJ, et al: Human melanoma-initiating cells express neural crest nerve growth factor receptor CD271. Nature 466: $133-137,2010$

42. Imai T, Tamai K, Oizumi S, Oyama K, Yamaguchi K, Sato I, Satoh K, Matsuura K, Saijo S, Sugamura K and Tanaka N: CD271 defines a stem cell-like population in hypopharyngeal cancer. PLoS One 8: e62002, 2013

43. Tian J, Li X, Si M, Liu T and Li J: CD271+ osteosarcoma cells display stem-like properties. PLoS One 9: e98549, 2014

44. Chen J, Song W and Amato K: Eph receptor tyrosine kinases in cancer stem cells. Cytokine Growth Factor Rev 26: 1-6, 2015

45. Genander M and Frisén J: Ephrins and Eph receptors in stem cells and cancer. Curr Opin Cell Biol 22, 611-616, 2010.

46. Miao H, Gale NW, Guo H, Qian J, Petty A, Kaspar J, Murphy AJ, Valenzuela DM, Yancopoulos G, Hambardzumyan D, et al: EphA2 promotes infiltrative invasion of glioma stem cells in vivo through cross-talk with Akt and regulates stem cell properties. Oncogene 34: 558-567, 2015

47. Song W, Ma Y, Wang J, Brantley-Sieders D and Chen J: JNK signaling mediates EPHA2-dependent tumor cell proliferation, motility and cancer stem cell-like properties in non-small cell lung cancer. Cancer Res 74: 2444-2454, 2014.

48. Sugihara E and Saya H: Complexity of cancer stem cells. Int J Cancer 132: 1249-1259, 2013

49. Hadnagy A, Gaboury L, Beaulieu R and Balicki D: SP analysis may be used to identify cancer stem cell populations. Exp Cell Res 312: 3701-3710, 2006.

50. Tirino V, Desiderio V, Paino F, De Rosa A, Papaccio F, La Noce M, Laino L, De Francesco F and Papaccio G: Cancer stem cells in solid tumors: An overview and new approaches for their isolation and characterization. FASEB J 27: 13-24, 2013

51. Zhang Z, Liu L, Gomez-Casal R, Wang X, Hayashi R, Appella E, Kopelovich L and DeLeo AB: Targeting cancer stem cells with p53 modulators. Oncotarget: Apr 8,2016 (Epub ahead of print).

52. Luo Y, Nguyen N and Fujita M: Isolation of human melanoma stem cells using ALDH as a marker. Curr Protoc Stem Cell Biol 26: Unit 3.8, 2013.

53. Chen YC, Chen YW, Hsu HS, Tseng LM, Huang PI, Lu KH, Chen DT, Tai LK, Yung MC, Chang SC, et al: Aldehyde dehydrogenase 1 is a putative marker for cancer stem cells in head and neck squamous cancer. Biochem Biophys Res Commun 385: 307-313, 2009

54. Davies TF, Latif R, Minsky NC and Ma R: Clinical review: The emerging cell biology of thyroid stem cells. J Clin Endocrinol Metab 96: 2692-2702, 2011.

55. Klonish T, Hoang-Vu C and Hombach-klonish S: Thyroid stem cells and cancer. Thyroid 19: 1303-1315, 2009. 
56. Thomas D, Friedman S and Lin RY: Thyroid stem cells: Lessons from normal development and thyroid cancer. Endocr Relat Cancer 15: 51-58, 2008.

57. Takano T: Fetal cell carcinogenesis of the thyroid: A modified theory based on recent evidence. Endocr J 61: 311-320, 2014.

58. Takano T: Fetal cell carcinogenesis of the thyroid: Theory and practice. Semin Cancer Biol 17: 233-240, 2007.

59. Takano $\mathrm{T}$ and Amino N: Fetal cell carcinogenesis: A new hypothesis for better understanding of thyroid carcinoma. Thyroid 15: 432-438, 2005.

60. Chaffer CL, Brueckmann I, Scheel C, Kaestli AJ, Wiggins PA, Rodrigues LO, Brooks M, Reinhardt F, Su Y and Polyak K: Normal and neoplastic nonstem cells can spontaneously convert to a stem-like state. Proc Natl Acad Sci USA 108: 7950-7955, 2011.

61. Lan L, Luo Y, Cui D, Shi BY, Deng W, Huo LL, Chen HL, Zhang GY and Deng LL: Epithelial-mesenchymal transition induces cancer stem cell generation in human thyroid cancer cells in vitro. Zhonghua Yi Xue Za Zhi 93: 1261-1265, 2013 (In Chinese).

62. Hardin H, Montemayor-Garcia C and Llyod RV: Thyroid cancer stem-like cells and epithelial-mesenchymal transition in thyroid cancers. Hum Pathol 44: 1707-1713, 2013.

63. Yasui K, Shimamura M, Mitsutake N and Nagayama Y: SNAIL induces epithelial-to-mesenchymal transition and cancer stem cell-like properties in aldehyde dehydroghenase-negative thyroid cancer cells. Thyroid 23: 989-996, 2013.

64. Nagayama Y, Shimamura M and Mitsutake N: Cancer stem cells in the thyroid. Front Endocrinol (Lausanne) 7: 20, 2016.

65. Zito G, Richiusa P, Bommarito A, Carissimi E, Russo L, Coppola A, Zerilli M, Rodolico V, Criscimanna A, Amato $\mathrm{M}$, et al: In vitro identification and characterization of CD133(pos) cancer stem-like cells in anaplastic thyroid carcinoma cell lines. PloS One 3: e3544, 2008

66. Friedman S, Lu M, Schultz A, Thomas D and Lin RY: CD133+ anaplastic thyroid cancer cells initiate tumors in immunodeficient mice and are regulated by thyrotropin. PLoS One 4: e5395, 2009

67. Schweppe RE, Klopper JP, Korch C, Pugazhenthi U, Benezra M, Knauf JA, Fagin JA, Marlow LA, Copland JA, Smallridge RC and Haugen BR: Deoxyribonucleic acid profiling analysis of 40 human thyroid cancer cell lines reveals cross-contamination resulting in cell line redundancy and misidentification. J Clin Endocrinol Metab 93: 4331-4341, 2008.

68. Todaro M, Iovino F, Eterno V, Cammareri P, Gambara G, Espina V, Gulotta G, Dieli F, Giordano S, De Maria R and Stassi G: Tumorigenic and metastatic activity of human thyroid cancer stem cells. Cancer Res 70: 8874-8885, 2010.

69. Malaguarnera R, Morcavallo A, Giuliano S and Belfiore A Thyroid cancer development and progression: Emerging role of cancer stem cells. Minerva Endocrinol 37: 103-115, 2012.

70. Malaguarnera R, Frasca F, Garozzo A, Gianì F, Pandini G Vella V, Vigneri R and Belfiore A: Insulin receptor isoforms and insulin-like growth factor receptor in human follicular cell precursors from papillary thyroid cancer and normal thyroid. J Clin Endocrinol Metab 96: 766-774, 2011.

71. Li W, Reeb AN, Sewell WA, Elhomsy G and Lin RY: Phenotypic characterization of metastatic anaplastic thyroid cancer stem cells. PloS One 8: e65095, 2013

72. Ahn SH, Henderson YC, Williams MD, Lai SY and Clayman GL: Detection of thyroid cancer stem cells in papillary thyroid carcinoma. J Clin Endocrinol Metab 99: 536-544, 2014

73. Shimamura M, Nagayama Y, Matsuse M, Yamashita S and Mitsutake N: Analysis of multiple markers for cancer stem-like cells in human thyroid carcinoma cell lines. Endocr J 61: 481-490, 2014.

74. Hombach-Klonisch S, Natarajan S, Thanasupawat T, Medapati M, Pathak A, Ghavami S and Klonisch T: Mechanisms of therapeutic resistance in cancer (Stem) cells with emphasis on thyroid cancer cells. Front Endocrinol (Lausanne) 5: 37, 2014

75. Ke CC, Liu RS, Yang AH, Liu CS, Chi CW, Tseng LM, Tsai YF, Ho JH, Lee CH and Lee OK: CD133-expressing thyroid cancer cells are undifferentiated, radioresistant and survive radioiodide therapy. Eur J Nucl Med Mol Imaging 40: 61-71, 2013.

76. Zane M, Scavo E, Catalano V, Bonanno M, Todaro M, De Maria R and Stassi G: Normal vs cancer thyroid stem cells: The road to transformation. Oncogene 35: 805-815, 2016.

77. Gao YJ, Li B, Wu XY, Cui J and Han JK: Thyroid tumor-initiating cells: Increasing evidence and opportunities for anticancer therapy (review). Oncology Rep 31: 1035-1042, 2014.
78. Bhatia P, Tsumagari K, Abd Elmageed ZY, Friedlander P, Buell JF and Kandil E: Stem cell biology in thyroid cancer: Insights for novel therapies. World J Stem Cells 6: 614-619, 2014.

79. Soltanian S and Matin MM: Cancer stem cells and cancer therapy. Tumour Biol 32: 425-440, 2011.

80. Abroun S, Saki N, Ahmadvand M, Asghari F, Salari F and Rahim F: STATs: An old story, yet mesmerizing. Cell J 17: 395-411, 2015

81. Spitzner M, Ebner R, Wolff HA, Ghadimi BM, Wienands J and Grade M: STAT3: A novel molecular mediator of resistance to chemoradiotherapy. Cancers (Basel) 6: 1986-2011, 2014.

82. Tseng LM, Huang PI, Chen YR, Chen YC, Chou YC, Chen YW, Chang YL, Hsu HS, Lan YT, Chen KH, et al: Targeting signal transducer and activator of transcription 3 pathway by cucurbitacin I diminishes self-renewing and radiochemoresistant abilities in thyroid cancer-derived CD133+ cells. J Pharmacol Exp Ther 341: 410-423, 2012.

83. Peters $\mathrm{S}$ and Adjei AA: MET: A promising anticancer therapeutic target. Nat Rev Clin Oncol 9: 314-326, 2012.

84. Sierra JR and Tsao MS: c-MET as a potential therapeutic target and biomarker in cancer. Ther Adv Med Oncol 3 (Suppl): S21-S35, 2011.

85. Spitzweg C, Morris JC and Bible KC: New drugs for medullary thyroid cancer: New promises? Endocr Relat Cancer: May 16, 2016 (Epub ahead of print).

86. Plaza-Menacho I, Mologni L and McDonald NQ: Mechanisms of RET signaling in cancer: Current and future implications for targeted therapy. Cell Signal 26: 1743-1752, 2014.

87. Messina $M$ and Robinson BG: Technology insight: Gene therapy and its potential role in the treatment of medullary thyroid carcinoma. Nat Clin Pract Endocrinol Metab 3: 290-301, 2007.

88. Fletcher JI, Williams RT, Henderson MJ, Norris MD and Haber M: ABC transporters as mediators of drug resistance and contributors to cancer cell biology. Drug Resist Updat 26: 1-9, 2016.

89. Zheng X, Cui D, Xu S, Brabant G and Derwahl M: Doxorubicin fails to eradicate cancer stem cells derived from anaplastic thyroid carcinoma cells: Characterization of resistant cells. Int J Oncol 37: 307-315, 2010.

90. Fulawka L, Donizy P and Halon A: Cancer stem cells - the current status of an old concept: Literature review and clinical approaches. Biol Res 47: 66, 2014.

91.Zhao Y, Bao Q, Renner A, Camaj P, Eichhorn M, Ischenko I, Angele M, Kleespies A, Jauch KW and Bruns C: Cancer stem cells and angiogenesis. Int J Dev Biol 55: 477-482, 2011.

92. Yi SY, Hao YB, Nan KJ and Fan TL: Cancer stem cells niche: A target for novel cancer therapeutics. Cancer Treat Rev 39 290-296, 2013.

93. Raza U, Zhang JD and Sahin O: MicroRNAs: Master regulators of drug resistance, stemness and metastasis. J Mol Med (Berl) 92: 321-336, 2014

94. Hatfield S and Ruohola-Baker H: microRNA and stem cell function. Cell Tissue Res 331: 57-66, 2008

95. He L, Thomson JM, Hemann MT, Hernando-Monge E, Mu D, Goodson S, Powers S, Cordon-Cardo C, Lowe SW, Hannon GJ, and Hammond SM: A microRNA polycistron as a potential human oncogene. Nature 435: 828-833, 2005.

96. Calin GA, Dumitru CD, Shimizu M, Bichi R, Zupo S, Noch E, Aldler H, Rattan S, Keating M, Rai K, et al: Frequent deletions and downregulation of micro-RNA genes miR 15 and miR16 at 13 q14 in chronic lymphocytic leukemia. Proc Natl Acad Sci USA 99: 15524-15529, 2002

97. Vriens MR, Weng J, Suh I, Huynh N, Guerrero MA, Shen WT, Duh QY, Clark OH and Kebebew E: MicroRNA expression profiling is a potential diagnostic tool for thyroid cancer. Cancer 118: 3426-3432, 2012.

98. Forte S, La Rosa C, Pecce V, Rosignolo F and Memeo L: The role of microRNA in thyroid carcinomas. Anticancer Res 35 2037-2047, 2015.

99. Zhang X, Mao H and LV Z: MicroRNA role in thyroid cancer pathogenesis. Front Biosci (Landmark Ed) 18: 734-739, 2013.

100. Zhang J, Yang Y, Liu Y, Fan Y, Liu Z, Wang X, Yuan Q, Yin Y, Yu J,Zhu M, et al: MicroRNA-21 regulates biological behaviors in papillary thyroid carcinoma by targeting programmed cell death 4. J Surg Res 189: 68-74, 2014.

101. Lin X, Guan H, Li H, Liu L, Liu J, Wei G, Huang Z, Liao Z and Li Y: miR-101 inhibits cell proliferation by targeting Rac1 in papillary thyroid carcinoma. Biomed Rep 2: 122-126, 2014. 
102. Minna E, Romeo P, De Cecco L, Dugo M, Cassinelli G, Pilotti S, Degl'Innocenti D, Lanzi C, Casalini P and Pierotti MA: miR-199a-3p displays tumor suppressor functions in papillary thyroid carcinoma. Oncotarget 5: 2513-2528, 2014.

103.Lv M, Zhang X, Li M, Chen Q, Ye M, Liang W, Ding L, Cai H, Fu D and Lv Z: miR-26a and its target CKS2 modulate cell growth and tumorigenesis of papillary thyroid carcinoma. PloS One 8: e67591, 2013

104.Liu X, He M, Hou Y, Liang B, Zhao L, Ma S, Yu Y and Liu X: Expression profiles of microRNAs and their target genes in papillary thyroid carcinoma. Oncol Rep 4: 1415-1420, 2013.

105.Zhang X, Li M, Zuo K, Li D, Ye M Ding L, Cai H, Fu D, Fan Y and Lv Z: Upregulated miR-155 in papillary thyroid carcinoma promotes tumor growth by targeting APC and activating Wnt $/ \beta$-catenin signaling. J Clin Endocrinol Metab 98 : E1305-E1313, 2013

106. Wang Z, Zhang H, Zhang P, Li J, Shan Z and Teng W: Upregulation of miR-2861 and miR-451 expression in papillary thyroid carcinoma with lymph node metastasis. Med Oncol 30: 577, 2013

107. Chou CK, Yang KD, Chou FF, Huang CC, Lan YW, Lee YF, Kang HY and Liu RT: Prognostic implications of miR-146b expression and its functional role in papillary thyroid carcinoma. J Clin Endocrinol Metab 98: E196-E205, 2013.

108.Zhang J, Liu Y, Liu Z, Wang XM, Yin DT, Zheng LL, Zhang DY and $\mathrm{Lu} \mathrm{XB}$ : Differential expression profiling and functional analysis of microRNAs through stage I-III papillary thyroid carcinoma. Int J Med Sci 10: 585-592, 2013.

109. Pallante P, Visone R, Ferracin M, Ferraro A, Berlingieri MT, Troncone G, Chiappetta G, Liu CG, Santoro M, Negrini M, et al: MicroRNA deregulation in human thyroid papillary carcinomas. Endocr Relat Cancer 13: 497-508, 2006.

110. Stokowy T, Eszlinger M, Swierniak M, Fujarewicz K, Jarząb B, Paschke R and Krohn K: Analysis options for high-throughput sequencing in miRNA expression profiling. BMC Res Notes 7: 144,2014

111. Jikuzono T, Kawamoto M, Yoshitake H, Kikuchi K, Akasu H, Ishikawa H, Hirokawa M, Miyauchi A, Tsuchiya S, Shimizu K and Takizawa T: The miR-221/222 cluster, miR-10b and miR-92a are highly upregulated in metastatic minimally invasive follicular thyroid carcinoma. Int J Oncol 42: 1858-1868, 2013

112. Rossing M, Borup R, Henao R, Winther O, Vikesaa J, Niazi O, Godballe C, Krogdahl A, Glud M, Hjort-Sørensen C, et al: Down-regulation of microRNAs controlling tumourigenic factors in follicular thyroid carcinoma. J Mol Endocrinol 48: 11-23, 2012.

113. Puppin C, Durante C, Sponziello M, Verrienti A, Pecce V, Lavarone E, Baldan F, Campese AF, Boichard A, Lacroix L, et al: Overexpression of genes involved in miRNA biogenesis in medullary thyroid carcinomas with RET mutation. Endocrine 47: 528-536, 2014.
114. Hudson J, Duncavage E, Tamburrino A, Salerno P, Xi L, Raffeld M, Moley J and Chernock RD: Overexpression of miR-10a and miR-375 and downregulation of YAP1 in medullary thyroid carcinoma. Exp Mol Pathol 95: 62-67, 2013.

115. Reddi HV, Driscoll CB, Madde P, Milosevic D, Hurley RM McDonough SJ, Hallanger-Johnson J, McIver B and Eberhardt NL: Redifferentiation and induction of tumor suppressors miR-122 and miR-375 by the PAX8/PPAR $\gamma$ fusion protein inhibits anaplastic thyroid cancer: A novel therapeutic strategy. Cancer Gene Ther 20: 267-275, 2013.

116. Zhang Z, Liu ZB, Ren WM, Ye XG and Zhang YY: The miR-200 family regulates the epithelial-mesenchymal transition induced by EGF/EGFR in anaplastic thyroid cancer cells. Int J Mol Med 30: 856-862, 2012

117. Takakura S, Mitsutake N, Nakashima M, Namba H, Saenko VA, Rogounovitch TI, Nakazawa Y, Hayashi T, Ohtsuru A and Yamashita S: Oncogenic role of miR-17-92 cluster in anaplastic thyroid cancer cells. Cancer Sci 99: 1147-1154, 2008

118. Yu S, Liu Y, Wang J, Guo Z, Zhang Q, Yu F, Zhang Y, Huang K, $\mathrm{Li} \mathrm{Y}$, Song E, et al: Circulating microRNA profiles as potential biomarkers for diagnosis of papillary thyroid carcinoma. J Clin Endocrinol Metab 97: 2084-2092, 2012.

119. Lee JC, Zhao JT, Clifton-Bligh RJ, Gill A, Gundara JS, Ip JC, Glover A, Sywak MS, Delbridge LW, Robinson BG and Sidhu SB: MicroRNA-222 and microRNA-146b are tissue and circulating biomarkers of recurrent papillary thyroid cancer. Cancer 119: 4358-4365, 2013.

120. Takahashi RU, Miyazaki $\mathrm{H}$ and Ochiya $\mathrm{T}$ : The role of microRNAs in the regulation of cancer stem cells. Front Genet 4: 295, 2014

121. Hao J, Zhao S, Zhang Y, Zhao Z, Ye R, Wen J and Li J: Emerging role of microRNAs in cancer and cancer stem cells. J Cell Biochem 115: 605-610, 2014

122. Vira D, Basak SK, Veena MS, Wang MB, Batra RK and Srivatsan ES: Cancer stem cells, microRNAs, and therapeutic strategies including natural products. Cancer Metastasis Rev 31: 733-751, 2012.

123. Garg M: MicroRNAs, stem cells and cancer stem cells. World J Stem Cells 4: 62-70, 2012.

124. Hao J, Zhang Y, Deng M, Ye R, Zhao S, Wang Y, Li J and Zhao Z: MicroRNA control of epithelial-mesenchymal transition in cancer stem cells. Int J Cancer 135: 1019-1027, 2014.

125. Eramo A, Haas TL and De Maria R: Lung cancer stem cells: Tools and targets to fight lung cancer. Oncogene 29: 4625-4635, 2010 . 